\title{
Rancang Bangun Sistem Pengontrol Lampu Rumah Berbasis Mikrokontroler Arduino Uno Menggunakan Smartphone
}

\author{
Nano Sudin', Ilham Djufri' ${ }^{2}$, K Kasyif G Umar \\ Program Studi Teknik Komputer \\ Akademik Ilmu Komputer Ternate \\ nanosudin@yahoo.com
}

\begin{abstract}
Abstrak
Dalam suatu rumah lampu adalah salah satu dari Bagian yang penting, untuk mempermudah mematikan dan menghidupkan lampu dalam suatu rumah digunakan perantara Bluetooth yang terintegrasi pada smartphone android dan arduino uno. Keseluruhan rancangan ini terdiri dari beberapa bagian yaitu terdiri atas smartphone android, modul bluetooth HC-06, mikrokontroller arduino uno, modul relay, kabel, fitting lampu, adapter 5v DC dan lampu. Alat ini bekerja saat bluetooth smartphone menyambungkan koneksi ke bluetooth HC-06, dari Bluetooth HC-06 kemudian ke mikrokontroler untuk memproses perintah, dari mikrokontroler kemudian ke modul relay yang bekerja sebagai pengganti saklar yang berfungsi untuk menghidupkan atau mematikan lampu sesuai yang di inginkan. hasil pengujian yang menggunakan metode blackbox menunjukkan bahwa aplikasi HomeLightController pada smartphone Android dapat berkomunikasi dengan arduino uno dengan jarak $<15$ meter tanpa ada penghalang dan $<9$ meter jika ada penghalang.
\end{abstract}

Kata kunci: Smartphone, Bluetooth HC-06, Arduino uno, Relay, Lampu

\section{Abstract}

In a lamp house is one of the critical parts, to make it easy to turn off and turn on the lights in a home, use an integrated Bluetooth intermediary on android smartphones and Arduino Uno. The overall design consists of several parts consisting of an Android smartphone, Bluetooth HC-06 module, Arduino Uno microcontroller, relay module, cable, lamp fittings, $5 \mathrm{~V}$ DC adapter, and lights. This tool works when the Bluetooth smartphone connects to the Bluetooth HC-06 connection, from Bluetooth $\mathrm{HC}-06$, then to the microcontroller to process commands, from the microcontroller then to the relay module that works as a substitute for a switch that functions to turn on or turn off the lights as desired. Test results using the BlackBox method show that the HomeLightController Application on an Android smartphone can communicate with Arduino Uno with a distance of $<15$ meters without any obstacles and $<9$ meters if there are obstacles.

Keywords: Smartphone, Bluetooth HC-06, Arduino Uno, Relay, Lights

\section{PENDAHULUAN}

Seiring dengan berkembangnya teknologi yang sangat cepat pada zaman sekarang ini dengan tujuan untuk mempermudah kegiata manusia dalam kehidupan sehari-hari. Perkembangan pada mikrokontroller misalnya, telah membawa era baru dalam dunia elektronika. Salah satu penerapannya adalah pengontrolan mematikan dan menghidupkan lampu dalam suatu rumah menggunakan smartphone dengan memanfaatkan koneksi bluetooth.

Dalam perancangan ini penulis menggunakan mikrokontroller ATmega 328 (Arduino Uno) sebagai pengolahan data sekaligus menyinpan data program yang di perlukan dalam pengendalian 
lampu rumah. Disisi lain smartphone android semakin banyak tersedia di pasaran dengan harga yang semakin terjangkau. Dengan memanfaatkan fasilitas bluetooth yang di sediakan oleh smartphone memungkinkan untuk melakukan pengontrolan lampu rumah yang di hubungkan dengan rangkaian mikrokontroller dan relay. Pada dasarnya alat rancangan ini dapat di operasikan oleh orang yang mampu mengoperasikan smartphone agar dapat melakukan pengontrolan lampu sesuai yang di inginkan melalui smartphone tersebut.

Perencanaan penerapan hasil rancangan ini pada salah satu rumah dengan alamat fitu puncak RT/RW 003/006, Kecamatan ternate selatan, kota ternate, Provinsi Maluku Utara. Sebelum menerapkan alat rancangan ini, penulis mengimplementasikan hasil rancangan tersebut dalam bentuk prototype rumah, guna untuk mendemokan pada pengujian tugas akhir.

\section{Rumusan Masalah}

Berdasarkan yang telah di uraikan di atas, maka pokok masalah adalah bagaimana membuat suatu aplikasi dan sistem pengontrolan lampu rumah melalui smartphone dengan memanfaatkan koneksi bluetooth

\section{Tujuan Penelitian}

Tujuan penelitian yang ingin di capai adalah untuk menghasilkan suatu alat yang dapat mempermudah mengendalikan lampu rumah menggunakan smartphone melalui koneksi bluetooth yang saling terhubung.

\section{Manfaat Penelitian}

Untuk memberi kenyamanan dan kemudahan bagi pemilik rumah mengendalikan lampu rumah menggunakan smartphone.

\section{Tinjauan Pustaka}

Penelitian yang di lakukan oleh Miqdad Dwi Rezki (2015). Aplikasi pengotrolan lampu menggunakan aplikasi yang sudah tersedia dari Playstore google dan belum membahas jarak koneksi Bluetooth ke Smartphone Android ketika ada penghalang.

Andik giyartono, Priadhana edi kresnha (2015). Pembuatan aplikasi Android menggunakan Software Android Studio, dimana untuk menggunakan Software tersebut, spesifikasi yang di rekomendasi Random access memory (RAM) 4GB pada komputer. Jika spesifikasi di bawa dari yang di rekomendasikan maka laptop atau pc kita menjadi lambat dalam pembuata aplikas tersebut.

Evan taruna setiawan(2015). Pada aplikasi tidak dapat melihat daftar Device Bluetooth yang terdeteksi aktif dan memilih untuk mengkoneksikan ke Smartphone.

Adri Susanto, Ismain Darisman Jauhari(2018). Belum membahas tegangan maksilam dan minimal yang masuk ke Boar Arduino.

Juliandi Mandey, Merson Simbolon (2018). Belum membahas jarak maksimal dan miniml koneksi Bluetooth ke Smartphone Android ketika ada penghalang.

Nano sudin (2019). Pada aplikasi android belum terdapat tombol exit untuk memutuskan koneksi Bluetooth dengan smartphone dan belum dapat memberikan keterangan lebel pada aplikasi ketika tidak terkoneksi dengan Bluetooth (tidak terkoneksi) 


\section{LANDASAN TEORI}

\section{Mikrokontroller}

Anggraini (2014) Salah satu mikrokontroler yang banyak digunakan saat ini yaitu mikrokontroler AVR. AVR adalah mikrokontroler RISC (Reduce Instuction Set Compute) 8 bit berdasarkan arsitektur Harvard. Secara umum mikrokontroler AVR dapat dapat dikelompokkan menjadi 3 kelompok, yaitu keluarga AT90Sxx, ATMega dan ATtiny. Pada dasarnya yang membedakan masingmasing kelas adalah memori, peripheral, dan fiturnya Seperti mikroprosesor pada umumnya, secara internal mikrokontroler ATMega16 terdiri atas unit-unit fungsionalnya Arithmetic and Logical Unit (ALU), himpunan 4 register kerja, register dan dekoder instruksi, dan pewaktu beserta komponen kendali lainnya. Berbeda dengan mikroprosesor

\section{Mit app inventor}

Menurut Rumopa dan pembimbing (2015), App Inventor adalah aplikasi web sumber terbbuka yang awal di kembangkan oleh google, dan saat ini di kelola oleh Massachusetts Institute of Technology. App Inventor memungkinkan pengguna baru untuk memprogram komputer untuk menciptakan aplikasi perangkat lunak bagi sistem operasi Android.App Inventor menggunakan antarmuka grafis, serupa dengan antarmuka pengguna pada Scratch dan Starlogo TNG, yang memungkinkan pengguna untuk men-drag-and-drop obyek visual untuk menciptakan aplikasi yang bisa dijalankan pada perangkat Android. Dalam menciptakan App Inventor

\section{Arduino Uno}

Nugraha (2016) Arduino adalah komponen utama dalam sistem yang berfungsi sebagai pusat kendali.Arduino diperuntukan bagi seniman, desainer, hobiis dan siapa pun yang tertarik untuk membuat alat yang interaktif. Arduino secara fisik adalah mikrokontroler. Arduino adalah perangkat keras berbentuk rangkaian elektronik dengan ukuran yang kecil dan berfungsi sebagai kontroler. Dihubungkan dengan sensor yang akan memberikan informasi keadaan obyek atau lingkungan di sekitarnya, kemudian mengolah informasi tersebut lalu menghasilkan suatu aksi. Proses ini akan dilakukan berulang- ulang.

\section{Modul Bluetooth HC-06}

Kurnia Agung Pamungkas (2016) Bluetooth Module HC-06 merupakan module komunikasi nirkabel pada frekuensi $2.4 \mathrm{GHz}$ dengan default koneksi hanya sebagai SLAVE. Sangat mudah digunakan dengan mikrokontroler untuk membuat aplikasi wireless. Interface yang digunakan adalah serial RXD, TXD, VCC dan GND. Built in LED sebagai indikator koneksi bluetooth.

\section{Modul Relay}

Menurut Adrianto (2015) relay adalah komponen elektronika berupa saklar elektronik yang di kendalikan oleh arus listrik. Secara prinsip kerja relay merupakan tuas saklar denga lilitan kawat pada batang besi (solenoid) di dekatnya. Ketika solenoid di aliri arus listrik, tuas akan mendapatkan tarikan medan magnet yang di hasilkan solenoid sehingga kontak saklar akan menutup. Pada saat arus tidak di terima solenoid maka gaya akan hilang, dan saklar akan kembali terbuka

\section{Bahasa Pemrograman Arduino}

Syahwil (2013) menyatakan, bahwa banyak bahasa yang bisa digunakan untuk program mikrokontroler, misalnya bahasa assembly. Namun dalam pemrograman 
arduino bahasa yang dipakai adalah bahasa C.

\section{Smartphone}

Menurut Williams \& Sawyer (2011), smartphone adalah telepon selular dengan mikroprosesor, memori, layar dan modem bawaan. Smartphone merupakan ponsel multimedia yang menggabungkan fungsionalitas PC dan handset sehingga menghasilkan gadget yang mewah, di mana terdapat pesan teks, kamera, pemutar musik, video, game, akses email, tv digital, search engine, pengelola informasi pribadi, fitur GPS, jasa telepon internet dan bahkan terdapat telepon yang juga berfungsi sebagai kartu kredit

\section{Sistem Kontrol}

Yusron (2009) Sistem control adalah proses pengaturan atau pengendalian terhadap satu atau beberapa besaran (variabel, parameter) sehingga berada pada suatu harga range tertentu.

\section{METODE PENELITIAN}

Dalam penelitian tugas akhir ini, penulis menggunakan motode sebagai berikut :

\section{Studi Literatur}

Motode literatur merupakan tahapan dimana peneliti melakukan pembelajaran dari buku, jurnal, artikel, maupun referensi lain, yang tersedia secara onlinemaupun offline, yang berhubungan dengan penelitian yang dilakukan.

\section{Analisis}

Penulis melakukan analisis kebutuhan alat perancangan sistem dan permasalahan yang terjadi dalam peracangan tugas akhir ini.

\section{Implementasi}

Penulis melakuka pengujian hasil rancangan sistem pada prototype ruma yang telah di buat.

\section{Jalannya Penelitian}

Berikut jalannya penelitian dalam tugas akhir ini :

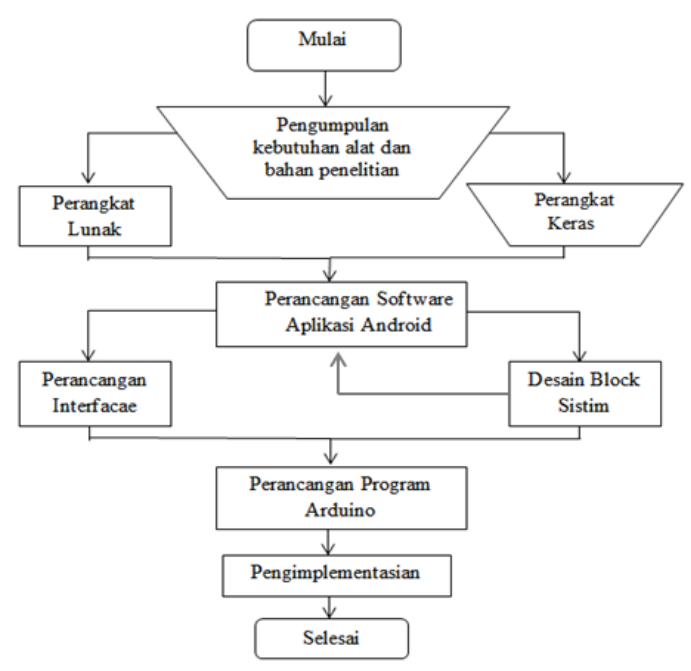

Gambar 1. Flowchart Penelitian

\section{ANALISIS DAN PERANCANGAN Analisis Kebutuhan}

Pada tahap ini dilakukan analisi kebutuhan alat dan bahan dalam perancanga tugas akhir ini, meliputi 2 komponen, yairu komponen perangkat keras (hardware) dan perangkat lunak (software) yang digunakan sebagai alat rancangan. Dalam mendukung penelitian tugas akhir ini penulis melakukan penelitian rancangan pada laboratorium aikom Ternate.

\section{Perangkat Keras (Hardware)}

Adapun perangkat keras yang di gunakan dalam perancangan ini adalah sebagai berikut :

Tabel 1. Perangkat keras 


\begin{tabular}{|l|l|}
\hline \multicolumn{1}{|c|}{ Perangkat } & \multicolumn{1}{c|}{ Spesifikasi / Tipe } \\
\hline Laptop Lenovo G-40 & $\begin{array}{l}\text { Processor Intel (R) Colelom (R) } \\
\text { CPU N2840 @216 GHz, RAM 2 } \\
\text { GB, Harddisk 500 GB }\end{array}$ \\
\hline Smartphone Android OPPO F3 & $\begin{array}{l}\text { Versi Android 6.0, Processor eight } \\
\text { core, RAM4 GB, ROM 64 GB }\end{array}$ \\
\hline Arduine & Arduine Uno \\
\hline Modul Bluetooth & HC-06 \\
\hline Modul Relay & $10 \mathrm{~A}, 250 \mathrm{VAC}$ \\
\hline Lampu & - \\
\hline Fitting Lampu & - \\
\hline Kabel jamper Arduine & - \\
\hline Adaptor & $5 \mathrm{VDC}$ \\
\hline
\end{tabular}

\section{Perangkat Lunak (software)}

Perangkat lunak yang di gunakan untuk membuat aplikasi ini adalah :

- Sistem Operasi Windows 732 bit

- Mozilla Firefox atau Google Chrome

- Arduino Ide 1.8.9

\section{Analisis Kelayakan}

Penulis melakukan analisis kelayakan alat yang di gunakan dalam perancangan tugas akhir ini untuk memastikan alat tersebut bisa digunakan sesuai yang di inginkan.

\section{Perancangan}

Motode perancangan dalam tugas akhir ini, terdiri dari 2 motode yaitu , perancangan hardware, pada motode ini terjadi setelah analisa kebutuhan alat dan bahan telah siap, maka bahan akan di rancang sesuai desain rancangan yang telah di buat. Sedangkan motode perancangan software adalah pembuatan aplikasi android dan program arduino agar dapat menylakan dan mematikan lampu rumah menggunakan smartphone dengan koneksi Bluetooth.

\section{Perancangan Software Aplikasi Android \\ Dalam perancangan software aplikasi android ini menggunakan Tools Application Integrated Development Environment Inventor ( App Inventor)}

sebagai builder aplikasi. App Inventor adalah sebuah aplikasi builder untuk membuat aplikasi yang berjalan di sistem operasi android yang di sediakan oleh googlelabs. Untuk bisa masuk ke home App inventor $\mathrm{di}$

haruskan memiliki akun google terlebih dahulu.

\section{Perancangan Sistem}

Dalam analisis dan perancangan tugas akhir ini, Data yang di input dari smartphone android akan di terima oleh modul Bluetooth yang terhubung pada sistem mikrokontroler arduino uno. Data seri tersebut di terjemahkan mikrokontroler arduino uno menjadi data parallel. Data paraller yang di hasilkan oleh mikrokontroler arduino uno di teruskan ke modul relay melalui indicator led yang berfungsi untuk memastikan apabila lampu hidup (ON), lampu juga akan hidup, begitu juga sebaliknya. Kemudian relay akan meneruskan data yang di terima untuk menghidupkan atau mematikan lampu. relay akan tidak aktif. Relay aktif akan menyambungkan aliran listrik utama ke lampu sehingga lampu menyala.

Secara umum, alur kerja perancangan sistem adalah user melakukan komunikasi dengan sistem dengan menggunakan ponsel android yang sudah terinstal aplikasi pengendali lampu rumah, melalui media Bluetooth. Ponsel android memberikan input ke arduino UNO yang bekerja dengan mendapatkan daya dari adaptor 5Volt. Arduino memproses inputan dan memberikan output berupa logika high (tegangan 5Volt) dan logika low (tegangan 0Volt) melalui pin yang sudah ditentukan. Pin arduino dihubungkan ke modul relay, sehingga ketika pin bertegangan 0Volt relay akan 
aktif dan sebaliknya ketika bertegangan 5Volt relay akan tidak aktif. Relay aktif akan menyambungkan aliran listrik utama ke lampu sehingga lampu menyala.

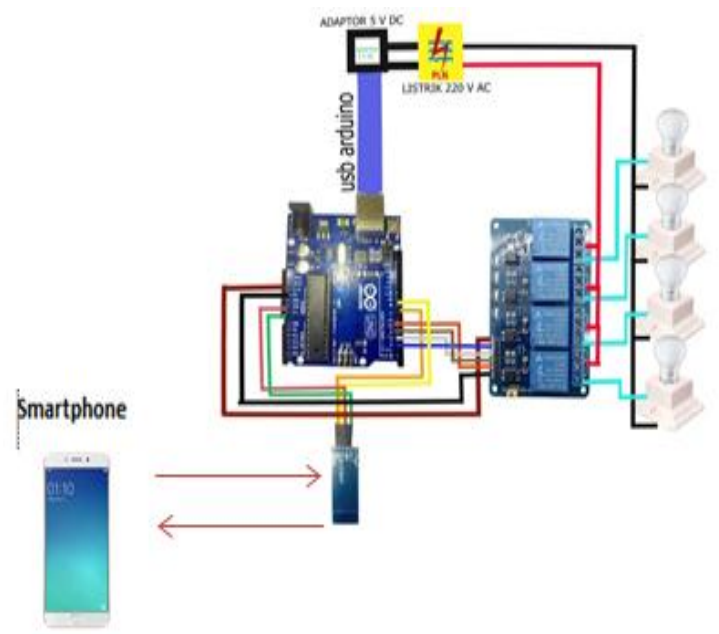

Gambar 2. Diagram Perancangan Sistem

Ket :

Tabel 2 Modul alat

\begin{tabular}{|c|c|}
\hline RX Pin Module Bluetooth & PIN 9 Arduino Uno \\
\hline TX Pin Module Bluetooth & PIN 8 Arduine Uno \\
\hline$+5 \mathrm{~V}$ Module Bluetooth & Vin Arduino Uno \\
\hline GND Module Bluetooth & GND Arduino Uno \\
\hline IN 1 Relay & PIN 2 Archino Uno \\
\hline IN 2 Relay & PIN 3 Arduine Uno \\
\hline IN 3 Relay & PIN 4 Arduino Uno \\
\hline IN 4 Relay & PIN 5 Arduino Uno \\
\hline GND Relay & GND Arduino Uno \\
\hline VCC Relay & $5 \mathrm{~V}$ Archino Uno \\
\hline
\end{tabular}

Arduino UNO mendapat sumber tegangan dari Adaptor 5V DC yang langsung dihubungkan ke listrik $220 \mathrm{~V}$ AC. RX dan TX modul Bluetooth dihubungkan ke pin 9 dan 8 Arduino UNO dan mengambil sumber tegangan (Vin) dari Arduino UNO. Pin IN1,IN2, IN3, dan IN4 Relay Modul dihubungkan ke pin 2, 3, 4,dan 5 Arduino UNO serta sumber tegangan $(5 \mathrm{~V})$ mengambil dari Arduino UNO juga. Output Relay Modul dihubungkan ke listrik utama dan lampu 1, 2, 3, dan 4 ke listrik utama dan NO1, NO2, NO3, NO4 ke lampu.

\section{IMPLEMENTASI DAN PEMBAHASAN}

Pengimplementasian dan pembahasan tugas akhir ini terdiri dari pengujian aplikasi yang di di buat sampai pengujian hasil rancangan di antaranya adalah :

\section{Aplikasi Android}

Dalam hal ini di mana ketika aplikasi pada smartphone android memberikan lebel " connected " berwarna hijau maka pengujian aplikasi berhasi seperti yang di harapkan.

Tabel 3. Pengujian aplikasi android

\begin{tabular}{|c|c|c|c|c|}
\hline No & Bluetooth & $\begin{array}{c}\text { Status } \\
\text { Bluetooth }\end{array}$ & Yang di Inginkan & Keterangan \\
\hline 1 & $\begin{array}{l}\text { Aktifkan } \\
\text { Bluetooth pada } \\
\text { smartphone }\end{array}$ & Aktif & $\begin{array}{l}\text { Menampilkan } \\
\text { device Bluetooth } \\
\text { yang aktif }\end{array}$ & Berhasil \\
\hline 2 & $\begin{array}{l}\text { Menekan logo } \\
\text { Bluetooth pada } \\
\text { aplikasi }\end{array}$ & Aktif & $\begin{array}{l}\text { Menampilkan } \\
\text { device Bluetooth } \\
\text { HC-06 }\end{array}$ & Berhasil \\
\hline 3 & $\begin{array}{l}\text { Memilih dan } \\
\text { menekan device } \\
\text { Bluetooth HC- } \\
06\end{array}$ & $\begin{array}{l}\text { Aktif dan } \\
\text { sudah } \\
\text { terkoneksi }\end{array}$ & $\begin{array}{l}\text { Dapat menamplkan } \\
\text { lebel " connected " } \\
\text { berwanah hijau } \\
\text { pada aplikasi. }\end{array}$ & Berhasil \\
\hline
\end{tabular}

\section{Adaptor}

Pengujian adaptor yang di gunakan sebagai sumber tegangan untuk mengaktifkan Arduino Uno, tegangan yang di butuhkan Arduino Uno sebesar 5-7 V DC. Adaptor tidak boleh $>18$ V DC, Saat Arduino Uno Menerima tengan $>18$ V DC maka Arduino Uno Menjadi tidak stabil dan tidak dapat menjalankan program. Pada pengujian ini, input adaptor di hubungkan langsung ke tegangan listrik $220 \mathrm{~V}$ AC.

Tabel 4.Seleksi adaptor 


\begin{tabular}{|c|c|c|l|}
\hline No & Tegangan Adaptor & Kondisi arduino & Keterangan \\
\hline 1 & 5V DC-17V DC & $\begin{array}{c}\text { Stabil dan dapat } \\
\text { menajalan } \\
\text { program }\end{array}$ & Berhasil \\
\hline 2 & & $\begin{array}{c}\text { Tidak stabil dan } \\
\text { tidak dapat } \\
\text { menjalankan } \\
\text { program }\end{array}$ & Tidak berhasil \\
& 18V DC atau lebih & \\
\hline
\end{tabular}

\section{Arduino Uno}

Pengujian arduino uno penulis menguji pin-pin pada arduino uno yang di gunakan dalam pembuatan alat rancangan ini, yaitu pin, 2, 3, 4, 5, 8, 9, GND, 5V, dan 3,3V. Dalam pengujian pin-pin arduino uno yang di gunakan penulis memastikan pin dapat bekerja sesuai apa yang di inginkan.

Tabel 5. Pengujian Arduino Uno

\begin{tabular}{|c|c|c|c|}
\hline No & Pin Arduino Uno & Yang Di Inginkan & Keterangan \\
\hline 1 & $2,3,4$, dan 5 & $\begin{array}{r}\text { Dapat memberikan logika 0/1 } \\
\text { sebagai output ke modul relay }\end{array}$ & Berhasil \\
\hline 2 & GND & Dapat menstabilkan tegangan & Berhasil \\
\hline 3 & $5 \mathrm{~V}$ & $\begin{array}{r}\text { Dapat memberikan tegangan ke } \\
\text { modul relay }\end{array}$ & Berhasil \\
\hline 4 & 3.3 & $\begin{array}{r}\text { Dapat memberkan tegangan ke } \\
\text { modul bletooth }\end{array}$ & Berhasil \\
\hline
\end{tabular}

\section{Pengujian Black Box}

Pengujian Black box penulis menguji hasil alat rancangan ini pada user sebanyak 30 orang dan penulis meminta tanggapan hasil pengujian mengenai perencanan penerapan pada suatu rumah dalam menyalankan dan mematikan lampu menggunakan smartphone android.

Dari hasil pengujian alat rancangan pada 31 orang terdiri dari 6 orang berjenis kelamin wanita dan 25 orang berjenis kelamin laki-laki. Dari tabel di atas maka tanggapan yang menerima perencanaan penerapan alat rancangan ini terdiri dari 19 orang dan cukup menerima perencanaan penerapan 5 orang dan yang belum menerima perencanaan penerapan 7 orang.

\section{Modul Bluetooth}

Pengujian Bluetooth menggunakan modul Bluetooth HC-06 di lakukan dengan cara memberikan tegangan sebesar 3-5 V dari Arduini Uno agar modul Bluetooth menjadi aktif. Selanjut di deteksi oleh smartphone android untuk mengetahui modul Bluetooth aktif dengan tidaknya. Ketika Modul Bluetooth HC06 di aktifkn maka hasilnya Modul Bluetooth terdeteksi dengan nama HC-06 pada device Bluetooth smartphone android. Tanpa ada penghalang Modul Bluetooth terdeteksi sampai jarak 16 meter, sedangkan dengan ada penghalang (dinding rumah) Modul Bluetooth terdeteksi sampai jarak 10meter. Hasil pengujian ini menunjukkan Modul Bluetooth berfungsi dengan baik.

Tabel 6. Pengujian koneksi Bluetooth

\begin{tabular}{|c|c|c|c|}
\hline No & Jarak & Tidak Terhalang & Terhalang \\
\hline 1 & $1-5$ meter & Terkoneksi & Terkoneksi \\
\hline 2 & 6 meter & Terkoneksi & Terkoneksi \\
\hline 3 & 7 meter & Terkoneksi & Terkoneksi \\
\hline 4 & 8 meter & Terkoneksi & Terkoneksi \\
\hline 5 & 9 meter & Terkoneksi & Terkoneksi \\
\hline 6 & 10 meter & Terkoneksi & Tidak Terkoneksi \\
\hline 7 & 11 meter & Terkoneksi & Tidak Terkoneksi \\
\hline 8 & 12 meter & Terkoneksi & Tidak Terkoneksi \\
\hline 9 & $13-15$ meter & Terkoneksi & Tidak Terkoneksi \\
\hline
\end{tabular}

\section{Module Relay}

Pengujian modul relay dimana jika diberi inputan logika low (0) maka lampu indicator akan menyala dan sebaliknya jika di beri logika high (1) maka lampu indicator akan mati. Pengujian Relay Modul dilakukan dengan cara memberi power. Relay Modul ( pin VCC dihubungan ke positif $5 \mathrm{~V}$ dan pin GND 
dihubungkan ke GND pada arduino ), selanjutnya pin IN1, IN2, IN3, dan IN4 secara bergantian diberi input $0 \mathrm{~V}$ (negatif). Hasil pengujian seperti tabel berikut :

Tabel 7. Pengujian Modul Relay

\begin{tabular}{|c|c|c|c|c|}
\hline No & $\begin{array}{c}\text { Pin Modul } \\
\text { Relay }\end{array}$ & $\begin{array}{c}\text { Inputan } \\
\text { Logika }\end{array}$ & $\begin{array}{c}\text { Indikator Lampu } \\
\text { Modul Relay }\end{array}$ & Keterangan \\
\hline \multirow{2}{*}{1} & \multirow{2}{*}{ IN 1 } & Low & Menyala & \multirow{2}{*}{ Berhasil } \\
\cline { 3 - 4 } & & High & Mati & \\
\hline \multirow{2}{*}{2} & \multirow{2}{*}{ IN 2 } & Low & Menyala & \multirow{2}{*}{ Berhasil } \\
\cline { 3 - 4 } & & High & Mati & \\
\hline \multirow{2}{*}{3} & \multirow{2}{*}{ IN 3 } & Low & Menyala & \multirow{2}{*}{ Berhasil } \\
\cline { 3 - 4 } 4 & IN 4 & High & Mati & \multirow{2}{*}{ Berhasil } \\
\cline { 3 - 4 } & & High & Menyala \\
\hline
\end{tabular}

Tabel di atas menunjukkan hasil pengujian Relay Modul. Ketika IN1 diberi input negatif lampu indikator IN1 menyala yang menunjukkan relay1 aktif dan selanjutnya ketika IN2, IN3, dan IN4, ketika diberi input negatif lampu indikatornya menyala. Hasil pengujian menunjukkan bahwa Relay Modul berfungsi dengan baik.

\section{Prototype Rumah}

Dalam pengujian pada prototype rumah merupakan pengujian akhir atau hasil perancangan, maka proses pengujian bagian ini yang di uji adalah inputan dari user dan output pada Arduino Uno. Berikut hasil pengujian :

Tabel 8. Pengujian Hasil Rancangan Sistem

\begin{tabular}{|c|c|c|c|c|c|c|}
\hline No & $\begin{array}{l}\text { Button } \\
\text { Aplikasi }\end{array}$ & $\begin{array}{c}\text { Lebel } \\
\text { Lampu }\end{array}$ & $\begin{array}{l}\text { Logika } \\
\text { Pin } \\
\text { Arduino }\end{array}$ & $\begin{array}{l}\text { Saklar } \\
\text { Relay }\end{array}$ & $\begin{array}{l}\text { Status } \\
\text { Lampu }\end{array}$ & Keterangan \\
\hline 1 & $\begin{array}{c}\text { Jika } \\
\text { menekan } \\
\text { button } 1\end{array}$ & $\begin{array}{c}\text { Lebel } \\
\text { lampu } 1 \\
\text { berubah } \\
\text { wama } \\
\text { hitam }\end{array}$ & $\begin{array}{l}\text { Pin } 2 \\
\text { low }\end{array}$ & $\begin{array}{c}\text { Relay } 1 \\
\text { aktif }\end{array}$ & $\begin{array}{l}\text { Lampu } 1 \\
\text { menyala }\end{array}$ & Berhasil \\
\hline 2 & $\begin{array}{c}\text { Jika } \\
\text { menekan } \\
\text { button } 2\end{array}$ & $\begin{array}{c}\text { Lebel } \\
\text { lampu } 1 \\
\text { berubah } \\
\text { wama } \\
\text { hitam }\end{array}$ & $\begin{array}{l}\text { Pin } 2 \\
\text { high }\end{array}$ & $\begin{array}{l}\text { Relay } 1 \\
\text { tidak } \\
\text { aktif }\end{array}$ & $\begin{array}{c}\text { Lampu } 1 \\
\text { tidak } \\
\text { menyala }\end{array}$ & Berhasil \\
\hline 3 & $\begin{array}{c}\text { Jika } \\
\text { menekan } \\
\text { button } 3\end{array}$ & $\begin{array}{c}\text { Lebel } \\
\text { lampu } 1 \\
\text { berubah } \\
\text { wama } \\
\text { hitam }\end{array}$ & $\begin{array}{l}\text { Pin } 3 \\
\text { low }\end{array}$ & $\begin{array}{c}\text { Relay } 2 \\
\text { aktif }\end{array}$ & $\begin{array}{l}\text { Lampu } 2 \\
\text { menyala }\end{array}$ & Berhasil \\
\hline 4 & $\begin{array}{c}\text { Jika } \\
\text { menekan } \\
\text { button } 4\end{array}$ & $\begin{array}{c}\text { Lebel } \\
\text { lampu } 1 \\
\text { berubah } \\
\text { wama } \\
\text { hitam }\end{array}$ & $\begin{array}{l}\text { Pin } 3 \\
\text { high }\end{array}$ & $\begin{array}{c}\text { Relay } 2 \\
\text { tidak } \\
\text { aktif }\end{array}$ & $\begin{array}{c}\text { Lampu } 2 \\
\text { tidak } \\
\text { menyala }\end{array}$ & Berhasil \\
\hline 5 & $\begin{array}{c}\text { Jika } \\
\text { menekan } \\
\text { button } 5\end{array}$ & $\begin{array}{c}\text { Lebel } \\
\text { lampu } 1 \\
\text { berubah } \\
\text { wama } \\
\text { hitam }\end{array}$ & $\begin{array}{l}\text { Pin } 4 \\
\text { low }\end{array}$ & $\begin{array}{c}\text { Relay } 3 \\
\text { aktif }\end{array}$ & $\begin{array}{l}\text { Lampu } 3 \\
\text { menyala }\end{array}$ & Berhasil \\
\hline 6 & $\begin{array}{c}\text { Jika } \\
\text { menekan } \\
\text { button } 6\end{array}$ & $\begin{array}{c}\text { Lebel } \\
\text { lampu } 1 \\
\text { berubah } \\
\text { wama } \\
\text { hitam }\end{array}$ & $\begin{array}{l}\text { Pin } 4 \\
\text { high }\end{array}$ & $\begin{array}{l}\text { Relay } 3 \\
\text { tidak } \\
\text { aktif }\end{array}$ & $\begin{array}{c}\text { Lampu } 3 \\
\text { tidak } \\
\text { menyala }\end{array}$ & Berhasil \\
\hline 7 & $\begin{array}{c}\text { Jika } \\
\text { menekan } \\
\text { button } 7\end{array}$ & $\begin{array}{c}\text { Lebel } \\
\text { lampu } 1 \\
\text { berubah } \\
\text { wama } \\
\text { hitam }\end{array}$ & $\begin{array}{l}\text { Pin } 5 \\
\text { low }\end{array}$ & $\begin{array}{c}\text { Relay } 4 \\
\text { aktif }\end{array}$ & $\begin{array}{l}\text { Lampu } 4 \\
\text { menyala }\end{array}$ & Berhasil \\
\hline 8 & $\begin{array}{c}\text { Jika } \\
\text { menekan } \\
\text { button } 8\end{array}$ & $\begin{array}{c}\text { Lebel } \\
\text { lampu } 1 \\
\text { berubah } \\
\text { wama } \\
\text { hitam }\end{array}$ & $\begin{array}{l}\text { Pin } 5 \\
\text { high }\end{array}$ & $\begin{array}{l}\text { Relay } 4 \\
\text { tidak } \\
\text { aktif }\end{array}$ & $\begin{array}{c}\text { Lampu } 4 \\
\text { tidak } \\
\text { menyala }\end{array}$ & Berhasil \\
\hline
\end{tabular}

Bila menekan (Button 1/ ON) maka lebel ( Lampu 1) berubah warna merah, data "a" di kirim ke arduino uno, pin 2 berlogika Low (0), di terima relay, saklar relay akan aktif dan lampu menyala.

Bila menekan (Button 1/ ON) maka lebel ( Lampu 1) berubah warna merah, data "a" di kirim ke arduino uno, pin 2 berlogika Low (0), di terima relay, saklar relay akan aktif dan lampu menyala.

Bila menekan (Button 3/ ON) maka lebel ( Lampu 2) berubah warna merah, data "b" di kirim ke arduino uno, pin 3 berlogika Low (0), di terima relay, saklar relay akan aktif dan lampu menyala

Bila menekan (Button 3/ ON) maka lebel ( Lampu 2) berubah warna merah, data " $b$ " di kirim ke arduino uno, pin 3 berlogika Low (0), di terima relay, saklar relay akan aktif dan lampu menyala

Bila menekan (Button 5/ ON) maka lebel ( Lampu 3) berubah warna merah, 
data "c" di kirim ke arduino uno, pin 4 berlogika Low (0), di terima relay, saklar relay akan aktif dan lampu menyala.

Bila menekan (Button 7/ ON) maka lebel ( Lampu 4) berubah warna merah, data "d" di kirim ke arduino uno, pin 5 berlogika Low (0), di terima relay, saklar relay akan aktif dan lampu menyala.

\section{KESIMPULAN}

Berdasar perancangan sistem, pembuatan alat serta dari pengujianpengujian yang telah dilakukan, dapat dibuat beberapa kesimpulan, antara lain :

1. Rangkaian alat terdiri dari Adaptor 5V, Arduino UNO, Modul Bluetooth HC-06 serta Relay modul sebagai pengganti saklar untuk memutus dan menyambung aliran listrik ke lampu rumah.

2. Aplikasi android dibuat dengan pada MIT App Inventor berbasis web serta penulisan program untuk Arduino UNO menggunakan software Arduino IDE 1.8.9 (Integrated Development Invironment).

3. Alat simulasi berupa prototipe rumah yang dibuat dari bahan triplek $1,5 \mathrm{~mm}$ dengan ukuran T. $90 \mathrm{~cm} \mathrm{x} \mathrm{L.60} \mathrm{cm} \mathrm{x}$ P.40 cm yang dibagi menjadi 4 ruangan yaitu ruangan , 2 ruangan pada lantai 1, 2 ruangan pada lantai 2, dan Masing-masing ruangan diberi lampu 5 Watt/220VAC.

4. Berdasar hasil pengujian yang dilakukan, alat dapat bekerja dengan baik untuk mengendalikan lampu rumah dengan jarak maksimal 16 meter tanpa ada penghalang dan 9 meter jika ada penghalang (Tembok rumah).

\section{Saran}

Uraikan saran dan keterbatasan penelitian diuraikan sebagai berikut:

1. Jarak yang dapat dijangkau maksimal hanya $<16$ meter tanpa penghalang dan $<10$ meter jika ada penghalang karena media penghubung yang digunakan Bluetooth. Penelitian berikutnya dapan dapan mengemabangkan dalam pengontrolan berupa hidup dan matikan mesin dengan cara yang sama maupun online,sms dan sebagainya.

2. Pada aplikasi android belum terdapat tombol exit putuskan koneksi Bluetooth. Peneliti berikutnya dapat mengembangkan aplikasi dengan menambahkan tombol exit dan tombol putuskan koneski Bluetooth atau menambah menu-menu lainnya.

\section{DAFTAR PUSTAKA}

Andik giyartono \& Priadhana edi kresnha, 2014. Aplikasi android pengendali lapu rumah berbasis mikrikontroler ATMEGA 328

(https://scholar.google.co.id/scholar? $\mathrm{hl}=\mathrm{id} \&$ as_sdt $=0 \% 2 \mathrm{c} 5 \&$ as_ylo $=2014$ \&scioq/ Di akses 27 oktober 2018, 22: 30 WIT)

Andri Susanto \& Ismail Darisman Jauhari, 2018. Rancang Bangun Aplikasi Android Untuk Kontrol Lampu Gedung Menggunakan Media Bluetooth Berbasis Arduino Uno (https://jurnal.umt.ac.id/index.php/jte/ article/download/635/434/ di askese 27 agustus 2018, 01:05 WIT).

Cerdas, Gerai. Bluetooth Module HC-06. http://www.geraicerdas.com/produkterbaru/bluetooth-module-hc-06detail. 10 Maret 2015. / Di akses 1 nobemver 2018, 24:21 WIT)

Djuandi. Feri, 2011, Pengenalan Arduino EBook,

(www.tokobuku.com. /Diakses 05 oktober 2018 02: 21 WIT). 
Dinda Tisi Calista, 2013. Modul Bluetooth HC-05 Pada Adrduino, (https://dindatc.wordpress.com/2014/ 04/18/mencoba-modul-bluetooth-hc05- pada arduino. / Diakses pada tanggal 02 November 2018,21: 23 WIT)

Evan Taruna Setiawan, 2015. Pengendalian Lampu Rumah Berbasis Mikrontroler Arduino Menggunakan smartphone android,

(http://lppm.atmaluhur.ac.id/wpcontent/up loads/2015/12/Jurnal_1111500064_E van-Taruna.pdf. /di akses 27 september 2108, 22:03 WIT).

Elektronika Teknik, 2017, Modul Rely, Rancang Bangun Aplikasi Android Untuk Kontrol Lampu Gedung Menggunakan Media Bluetooth Berbasis Arduino Uno, Halaman 2.

(https://jurnal.umt.ac.id/index.php/jte/artic le/download/635/434/ di askese 27 agustus 2018, 01:05 WIT).

Ir. Yuniar Supardi, 2014. Semua bisa menjadi programmer android. Penerbit PT Elex Media KomputindaJakarta , 2011

Inkubatok tekonologi miti Yogyakarta ,2018, control 4 lampu via android. Reviuw modul. Tempo 1 juli 2019

Juliandi Mandey \& Merson Simbolon, 2018. Kontrol Lampu Rumah Berbasis Smartphone Androidhomebased Smartphone Controls Android Smartphone, (https://jurnal.teknikunkris.ac.id/index .php/SEMNASTEK/article/download/ 110/107 /. / di akses 27 agustus 2018, 24: 23 WIT).

Muchlis, (2010), Definisi Mikrokontroler, Kontrol Lampu Rumah Berbasis Smartphone Androidhomebased Smartphone Controls Android Smartphone, Halaman 2.

(https://jurnal.teknikunkris.ac.id/index .php/SEMNASTEK/article/view/110/. / di akses 27 agustus 2018, 24: 23 WIT).
Nugraha, 2016, Sekilas Tentang Arduino, Kontrol Lampu Rumah Berbasis Smartphone Androidhomebased Smartphone Controls Android Smartphone, Halaman 2,

(https://jurnal.teknikunkris.ac.id/index.php /SEMNASTEK/article/view/110/. / di akses 27 agustus 2018, 24: 23 WIT).

Prodi Teknik Komputer AIKOM Ternate, 2017, modul pratikum interfacing. (Modul). Ternate :Progam D3 teknik computer.

Rumopa and Pembimbing, 2015, Mit app inventor, Rancang Bangun Aplikasi Android Untuk Kontrol Lampu Gedung Menggunakan Media Bluetooth Berbasis Arduino Uno, Halaman 1.

(https://jurnal.umt.ac.id/index.php/jte/ article/download/635/434/ di askese 27 agustus 2018, 01:05 WIT).

Rumimper 2016, Bluetooth Module HC05, Kontrol Lampu Rumah Berbasis Smartphone Androidhomebased Smartphone Controls Android Smartphone, Halaman 2,

(https://jurnal.teknikunkris.ac.id/index .php/SEMNASTEK/article/view/110/. / di akses 27 agustus 2018, 24: 23 WIT).

Syahban Rangkuti, 2016, Arduino dan Proteus.Penerbit INFORMATIKA, 